\title{
Comparative Leaf Surface Anatomy of Woody Species of Tamaulipan Thornscrub, North-Eastern Mexico and its Possible Relation with Taxonomic Delimitation and Drought Resistance
}

\author{
Humberto Gonzalez Rodriguez ${ }^{1 *}$, Ratikanta Maiti ${ }^{1}$, Perla Cecilia Rodriguez Balboa ${ }^{1}$, Jose Guadalupe Marmolejo Moncivaias ${ }^{1}$ \\ and Aruna Kumari²
}

\author{
${ }^{1}$ Universidad Autonoma de Nuevo Leon, Facultad de Ciencias Forestales, Carr. Nac. No. 85 Km. 45, \\ Linares, Nuevo Leon (67 700), Mexico \\ ${ }^{2}$ Crop Physiology, Prof. Jaya Shankar Telangana State Agricultural University, Agricultural College, \\ Polasa, Jagtial, Karimnagar, Telangana (505 529), India
}

\section{Article History}

Manuscript No. AR1644c

Received in $30^{\text {th }}$ July, 2016

Received in revised form $22^{\text {nd }}$ September, 2016

Accepted in final form $5^{\text {th }}$ October, 2016

\section{Correspondence to}

*E-mail: humberto.gonzalezrd@uanl.edu.mx

\section{Keywords}

Leaf surface, anatomy, stomata, woody

plants, taxonomy, adaptation

\begin{abstract}
A comparative study has been undertaken during May to July, 2016 in Forest Science Faculty Experimental Research Station, UANL, Mexico on the leaf surface anatomy of 30 native woody species of the Tamaulipan Thorn Forest and its utility in taxonomy and possible adaptation to the prevailing semiarid conditions. The results showed the presence of large variability in several leaf anatomical traits viz., waxy leaf surface, type of stomata, its size, and distribution. Some of the species possess special traits related to adaption in the environments such as waxy leaf surface, sunken stomata, the absence of stomata on the adaxial and or abaxial surface, thereby reducing loss in transpiration mentioned before. The presence of waxy leaf surface in most of the species such as Amyris texana, Celtis pallida, Guaiacum angustifolium, Acacia berlandieri, Karwinskia humboldtiana could help in the reflectance of solar radiation, thereby keeping leaf temperature cooler. The species have been classified on the basis of various traits which can be used in species delimitation and adaptation to the semiarid condition such as waxy leaf surface, absence or sparse stomata on the leaf surface, sunken stomata. The species identified as better adapters to semiarid environments on the basis of the presence and absence of stomata on both adaxial and abaxial surface such as: Berberis chochoco, Celtis laevigata, Condalia hookeri, Diospyros palmeri, Diospyros texana, Ebenopsis ebano, Ehretia anacua, Forestiera angustifolia, Havardia pallens, Helietta parvifolia, Karwinskia humboldtiana, Sargentia greggii, Sideroxylon celastrinum, Zanthoxylum fagara. Research is needed to confirm water relations and drought resistance of these selected species.
\end{abstract}

\section{Introduction}

Leaves play a vital role in the productivity of plants in a forest ecosystem through photosynthesis, gas exchange $\left(\mathrm{CO}_{2}, \mathrm{O}_{2}\right)$, and transpiration through stomata. Leaf surface acts as boundary between atmosphere and internal leaf tissue; therefore, any changes in climate affect greatly the metabolic functions in the leaves. Similarly, stomata plays an important role in these vital functions through stomata pores. The types and size of stomata vary greatly among species, used in the taxonomic determination of the species along with leaf anatomical features. Leaf anatomical traits play an important role in the taxonomic delimitation of species and its relation to adaptation to environment such as arid or semiarid conditions. Various studies have demonstrated the use of leaf anatomical traits in the taxonomic delimitation of the species; few examples are cited here. Three Brazilian species viz., Peperomia dahlstedtii CDC., Ottonia martiana Miq. and Piperdios pyrifolium Kunth showed structural similarity among themselves (Souza et al., 2004); 293 trees of Pseudotsuga in Mexico demonstrated significant differences (Reyes Hernandez et al., 2005, taxonomic delimitation of twelve species of Populus (Afas et al., 2007); and 35 species of the genus Kalanchoe Adans (Crassulaceae) demonstrated variations (Chernetskyy, 2012). Recently, the taxonomic delimitation of different species of Chamaecrista (L.) Moench sect. Apoucouita (Leguminosae-Caesalpinioideae) were done effectively (Coutinho et al., 2016). 25 Ficus species were distinguished effectively on anatomical basis demonstrating 
that multilayered hypodermis, one to three layers palisade parenchyma are the characteristic features to distinguish species (Sonibare et al., 2016).

Few studies demonstrate the use of numerical data in taxonomy. Ten species of Crocus have been investigated numerically (variance analysis and correlation) revealed that palisade cell height and spongy cell width are best parameter to distinguish species (Ozdemir and Ozdemir, 2010).

On the other hand, few studies discuss the role of the anatomical traits in the adaptation of the species to different habitats. In this regard, a study has demonstrated that leaf anatomical characteristics of Solanum nigrum from different habitats in Europe and in Yugoslavia showed variability in terms of stomata number, number of hairs, thickness of lamina, palisade and spongy tissue, as well as the size of mesophyll cells of the species collected from different localities (Krstic et al., 2002). A similar study carried out on the anatomical basis of resistance on plant species of a typical arid Mediterranean co system confirms the presence of several adaptive properties for the macchiae co system. Among these the presence of ergastic substances, mainly tannins and calcium oxalate in internal tissue in most of the species act with defensive functions, necessary in the adaptive resistance of plants to waters tress. Nearly all the species showed adaptations for protection against the photo damage possibly induced from the strong UV-B solar irradiance in summer. The more significant anatomical features were the trichomes, present on the abaxial surfaces of leaves, which maintained water budget of the plants both by influencing the diffusion boundary layer of the leaf surface and by regulating leaf optical parameters and, leaf temperature. In many species, trichomes or wax layers reduced radiation absorbance; two or three layers of palisade parenchyma presumably provide a better efficiency in utilizing the photosynthetic light. In almost every plant examined, stomata were sunken or well protected (Rotondi et al., 2003).

A comparative study made in Venezuela on leaf epidermis of an orchid, Cattleya jenmanii in vitro conditions demonstrated that compared to normal ones, the epidermal cells showed larger in size, lower anticlinal cell wall, lower size of stomata for adaptation of orchid, the leaves suffered changes in cells with an increase of mechanical resistance and rigidity (Torres et al., 2006). An eco-physiological study undertaken on two urban forestry species (Azadirachta indica and Millettia thonningii) revealed that the pattern of transpiration in $M$. thonningii was low in the morning, high in the noon and low in the afternoon. Leaf anatomical study revealed the presence of thick cuticle and high stomatal frequency in A. Indica and a low stomatal frequency in M. Thonningii (Dzomeku and Enu-Kwes, 2006). Noman et al. (2006) demonstrated the significant inter-cultivar differences among Hibiscus cultivars in leaf anatomical characteristics. It was concluded that anatomical genetic potential has endorsed cultivars Lemon chiffon and Wilder's white with enormous capability to grow well under variable environments. A study undertaken on the leaf anatomy of 15 species of vascular plants occurring in coastal zones of the Falcon State (Venezuela) revealed that the development of water storing tissue in the mesophyll and/or epidermal cells is the main characteristic associated with the saline habitat in those species. Besides, other characteristics of potential adaptive value were: presence of trichomes, stomata protected by papillae, crystals in mesophyll cells, secretory tissues, and Kranz anatomy (Garcia et al., 2008).

Some leaf epidermal traits could be related to adaptation to abiotic stresses. In this respect, a study undertaken on the foliar anatomy of shrubs in the semiarid region in Argentina, revealed that some of the characters related to adaptation were stellate trichomes in Capparicordis tweediana and Ruprechtia triflora, cystolitic trichomes in Celtis species, and multicellular peltate scales in Zanthoxylum coco. Presence of papillose epidermis (e.g., Schinopsis lorentzii); ciclocytic stomata in Bulnesia sarmientoi, Maytenus vitis-idaea, Moya spinosa and Schinopsis spp; idioblastic crystalifer epidermal cells (Scutia buxifolia); crystaliferous epidermis (Maytenus vitis-idaea); multilayered epidermis (Jodina rhombifolia); presence of hypodermis in Castela coccinea, Maytenus vitisidaea, Prosopis ruscifolia and Ziziphus mistol; bicollateral vascular bundles in Lycium cestroides; presence of crystals and in Calycophyllum multiflorum and Lycium cestroides absolute absence of crystals in the family Capparaceae (Arambarri et al., 2011). In another study, Arambarri et al. (2012) evaluated leaf anatomical traits in Chacoan forests in Argentina such as the density of epidermal cells, stomata and trichomes, mesophyll types and the type and distribution of vascular and sclerenchymatic tissues. Most trees of Chacoan Oriental possessed distinct hypostomatic leaves with dorsi ventral mesophyll and had a high density of epidermal cells $\left(4000-7000 \mathrm{~mm}^{-2}\right)$, intermediate density of stomata (300-500 $\left.\mathrm{mm}^{-2}\right)$ and low density of trichomes $\left(<35 \mathrm{~mm}^{-2}\right)$. Subsequently, a study undertaken on morpho-anatomical characteristics of Celtis ehrenbergiana revealed that its shade leaf structure was bifacial; epidermis was with wavy-sinuous anticlinal cell walls, mesophyll formed by palisade and spongy parenchyma, and angular-lacunar collenchyma. The sun leaf type had a thick leaf-limb which was leathery and dark green and its anatomical structure was equifacial, epidermis with straight anticlinal cell walls, mesophyll formed by homogeneous palisade parenchyma, and angular-massive collenchyma. There was nothing to scarcely stomata on adaxial surface in shade type 
leaf, however there were numerous in the sun type leaf. Celtis ehrenbergiana exhibited phenotypic plasticity indicating that it might be able to survive the climatic changes because of its adaptability and has an advantage over other species (Nughes et al., 2013).

In the context of above literature, the objective of the present study is to investigate the variability in leaf dermal characteristics of thirty woody species in North-eastern Mexico and its possible relation to taxonomic delimitation and adaptation of the species in xeric conditions.

\section{Materials and Methods}

A study was undertaken during May to July, 2016 on the qualitative and quantitative characterization of dermal anatomy of few native woody species of North-eastern Mexico (Table 1). We adopted the following technique for characterization of leaf surface anatomy.

\subsection{Technique}

Small pieces of thermocol are slowly dissolved in small amount of xylene in a petri dish to bring to a consistency of honey. Then, the solution is applied with the help of little finger on both upper and lower surface of leaves of each species in the region in between the midrib and margin. Then, they are left on the table for drying. Once dried, a piece of transparent tape is applied and pressed on the region with a finger. Finally the tape is taken out with leaf impression and pressed on a slide in the same direction. Now it is permanent and ready to observe under microscope.

\subsection{Characterization of leaf surface anatomy}

Using technique mentioned we took impression of leaf surface (both adaxial and abaxial surface) of 30 species to study the anatomical variability of the species.

\subsection{Quantification of stomata on leaf surface}

In our study, the measurement of stomata is difficult to assess owing to the fact that some species show absence of stomata and possess sunken stomata. Data were taken on stomatal counts and size of 30 species owing to the absence and or to the presence of sunken stomata in most of the species. Stomata were counted $\mathrm{mm}^{-2}$ of leaf surface. With the help of an ocular micrometer we measured the length and breadth of 50 stomata of each species and counted the number of stomata unit ${ }^{-1}$ area of leaf surface.

\section{Results and Discussion}

The present study was aimed to determine the variability in leaf surface anatomy and its possible relation to the taxonomic delimitation and adaptation of the trees and shrubs to xeric habitats of Tamaulipan Thorn scrub exposed to hot summer and cold climate. The results revealed that the species showed a large variability in stomatal presence and abundance on the adaxial and abaxial leaf surface. Besides, a large variability existed in the type and size of stomata, its sunken habit, epidermal cell structure which could be utilized in taxonomic delimitation of species and adaptation to abiotic and biotic stress. In this study, we concentrated mainly on stomatal characteristics (Plates 1 to 3). Each species had specific epidermal and stomatal characteristics to distinguish from each other. There existed large variation in size and form, intensity of epidermal cells, types, size and intensity of stomata both on the adaxial and abaxial surface. The present study was mainly concentrated on stomatal architecture, its distribution and abundance. Several species possessed sunken stomata as specific characteristics such as Celtis pallida, Guaiacum angustifolium, Forestiera angustifolia, Eysenhardtia texana, Parkinsonia texana, Gymnosperma glutinosum, Prosopis laevigata, Condalia hookeri, Diospyros palmeri. Besides there existed large variability in the form, shape and size of epidermal cells both on the adaxial and abaxial leaf surface. The woody trees and shrubs also showed a large variability in the types of stomata.

The species could be broadly be classified under the following heads-

\subsection{Types of stomata (old system)}

\subsubsection{Anomocytic}

Acacia berlandieri, Acacia farnesiana, Acacia schaffneri, Gymnosperma glutinosum, Celtis pallida, Celtis laevigata, Condalia hookeri, Diospyros palmeri, Leucaena leucocephala, Amyris madrensis, Berberis chochoco, Havardia pallens, Forestiera angustifolia, Gymosperma glutinosum, and Parkinsonia texana.

\subsubsection{Anisocytic}

Prosopis laevigata, Sideroxylon celastrinum.

\subsubsection{Paracytic}

Amyris texana, Eysenhardtia texana, Zanthoxylum fagara, Azadirachta indica

Apart from taxonomic delimitation, the presence and absence of stomata and its sunken nature could be related to the adaptation of the species to xeric habitats of Tamaulipan Thorn scrub.

\subsection{Presence and abundance of stomata on both adaxial and abaxial surface}

3.2.1. Class 1 (14 species: Very few or absence of stomata on the adaxial surface

Species with rare or absence of stomata on the adaxial leaf 
surface and very few stomata on the abaxial leaf surface (Plate 1). The species were Berberis chochoco, Celtis laevigata, Condalia hookeri, Diospyros palmeri, Diospyros texana, Ebenopsis ebano,, Ehretia anacua, Forestiera angustifolia, Havardia pallens, Helietta parviflora, Karwinskia humboldtiana, Sargentia greggii, Sideroxylon celastrinum, Zanthoxylum fagara. Most of these species possessed sunken stomata to maintain microclimate for adaptation to semiarid habitats. These species are expected to exhibit high stomatal control to prevent loss of water by transpiration.

3.2.2. Class 2 (11 species): Very few stomata on both adaxial and abaxial surface

The species were Acacia farnesiana, Acacia greggii, Acacia schaffneri, Caesalpinia mexicana, Celtis pallida, Eysenhardtia texana, Leucaena leucocephala, Parkinsonia aculeata, Parkinsonia texana, Prosopis laevigata (Plate 2). It is expected that these species are moderately susceptible to drought but could be resistant for other traits such as waxy leaf surface or deep root system.

3.2.3. Class 3 (5 species): Very few stomata on adaxial surface and many stomata on abaxial surface

Acacia berlandieri, Acacia rigidula, Amyris texana, Guaiacum angustifolium, Gymnosperma glutinosum (Plate 3). The species having many stomata are expected to be susceptible to drought, but these species might have deep root system for adaptation to drought situations.

\subsection{Stomatal density and size}

- Celtis pallida presented 51.5 stomata $\mathrm{mm}^{-2}$ on the adaxial surface but possessed $191.4 \mathrm{~mm}^{-2}$ on the abaxial surface.

- Condalia hookeri had $145.1 \mathrm{~mm}^{-2}$, the length and breadth of stomata were $20.6 \mu \mathrm{m}$ and $11.3 \mu \mathrm{m}$, respectively. The type of stomata amomocytic. Stomata are absent on the upper surface. Leaf surface waxy, glands present on the abaxial surface.

- Diospyros palmeri the length and breadth of stomata were $29.4 \mu \mathrm{m}$ and $19.4 \mu \mathrm{m}$, respectively. Stomata anomocytic, few stomata present on the adaxial surface, but very few on the abaxial surface, stomata anomocytic, glands present on the abaxial surface.

- Diospyros texana had on the abaxial surface 134.3 stomata $\mathrm{mm}^{-2}$, length and breadth of stomata were $28.4 \mu \mathrm{m}$ and 17.1 $\mu \mathrm{m}$, respectively. Stomata anomocytic, very few stomata on the adaxial surface, stomata are medium sunken.

- Helietta parvifolia, had stomata $74.9 \mathrm{~mm}^{-2}$ on the abaxial surface, length and breadth are $36.7 \mu \mathrm{m}$ and $18.3 \mu \mathrm{m}$, respectively. Stomata anisocytic, leaf surface waxy, but higher number of stomata present on the abaxial surface.

- Karwinskia humboldtiana had 517.0 stomata $\mathrm{mm}^{-2}$ length and breadth of stomata were $17.2 \mu \mathrm{m}$ and $10.1 \mu \mathrm{m}$, respectively.
Stomata anomocytic, very few stomata present or absent on the adaxial surface.

- In Sideroxylon celastrinu, stomata length and breadth were $22.3 \mu \mathrm{m}$ and $9.3 \mu \mathrm{m}$, respectively. Density of stomata was $155.2 \mathrm{~mm}^{-2}$. Very few stomata were present or absent on the adaxial surface. Stomata anisocytic.

- In Zanthoxylum fagara, stomata length and breadth were $21.95 \mu \mathrm{m}$ and $10.88 \mu \mathrm{m}$, respectively, stomata anomocytic, leaf surface waxy, few stomata present on the adaxial surface; some were present on the abaxial surface.

The results of the present study reveal that there exists a large variability in the type and size of stomata, epidermal cell and stomatal architecture which can be utilized in taxonomic delimitation of species and adaptation to abiotic and biotic stress. Therefore, there is a great necessity to study leaf surface structure of different species which may help in the taxonomic delimitation and adaptation of the species to xeric environments. It is also observed that there exist variation in stomata $\mathrm{mm}^{-2}$ and size of stomata among thirty species studied which influence water balance through control of transpiration.

It is well documented that leaf anatomical traits play an important role in taxonomy and adaptation of the tree species to environmental stress such as drought, cold and high temperature. The density of trichomes, cuticular thickness, compact palisade, presence of tannins, phenolics, other exudates is related to resistance to water loss. On the basis of these traits, the species can be categorized for their adaptation to different environments of abiotic and biotic stress.

Most of the species mentioned above are well adapted in semiarid regions of North-eastern Mexico for few adaptive traits. Besides the stomatal characteristics it is interesting to note that most of the species in Tamaulipan Thorn scrub possess few special characteristics such as waxy leaf surface and the presence of sunken stomata. Most of the species possess waxy leaf surface, which reflect solar radiation, thereby maintaining lower leaf temperature and water balance. We want to cite here only few species with a waxy surface such as Amyris texana, Celtis pallida, Guaiacum angustifolium, and Acacia berlandieri. Many species possessed sunken stomata mentioned earlier viz., Amyris texana, Celtis pallida, Guaiacum angustifolium, Forestiera angustifolia, Eysenhardtia texana, Parkinsonia texana, Gymnosperma glutinosum, Prosopis laevigata, Condalia hookeri, Diospyros palmeri, Diospyros texana, Karwinskia humboldtiana, Zanthoxylum fagara, Sideroxylon celastrinum, Leucaena leucocephala, and Ehretia anacua.

The results of the present study support the findings of various authors who used leaf anatomy in the taxonomic classification 

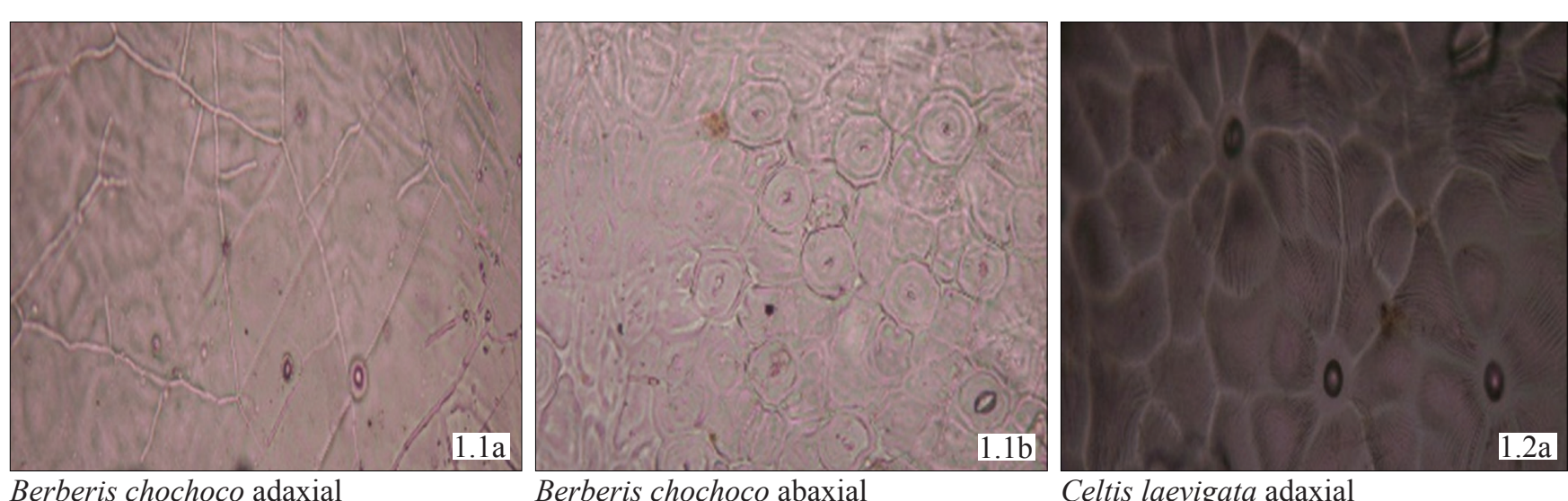

Berberis chochoco adaxial

Berberis chochoco abaxial

Celtis laevigata adaxial
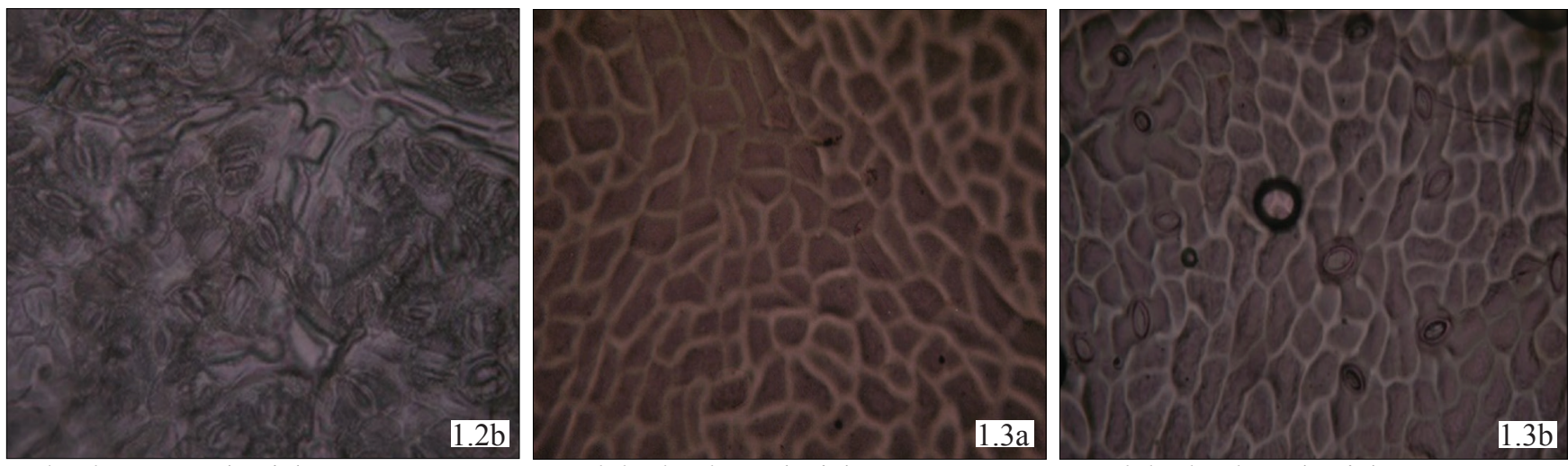

Celtis laevigata abaxial

Condalia hookeri adaxial

Condalia hookeri abaxial
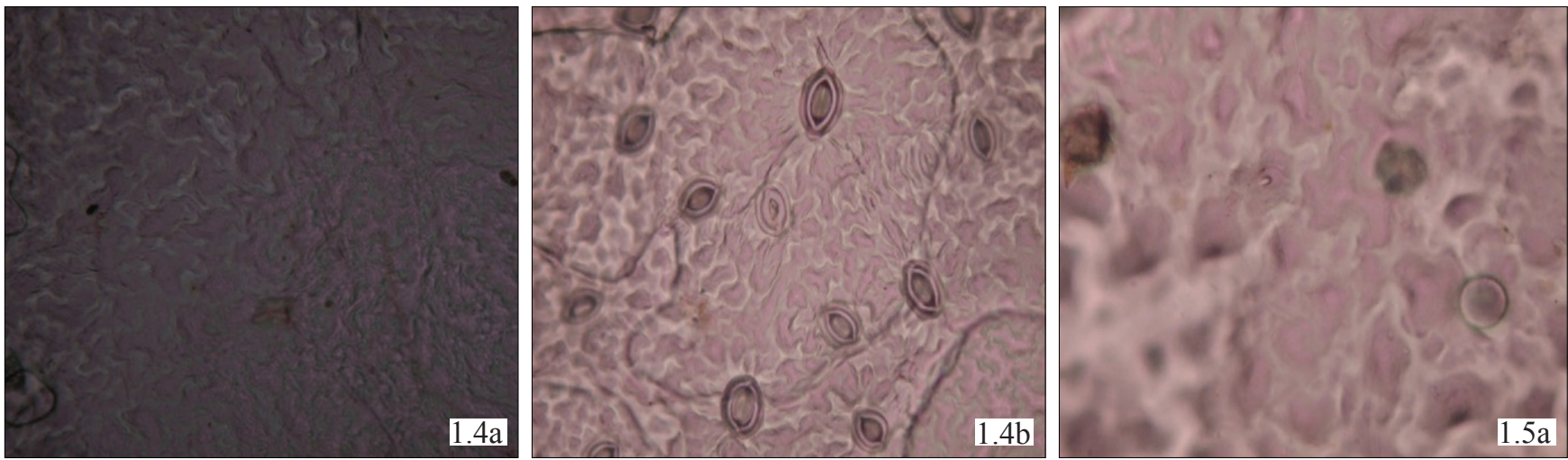

\section{Diospyros palmeri adaxial}

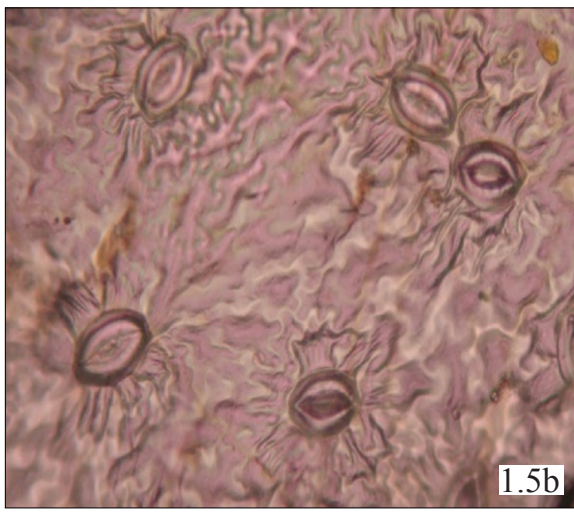

Diospyros texana abaxial

\section{Diospyros palmeri abaxial}

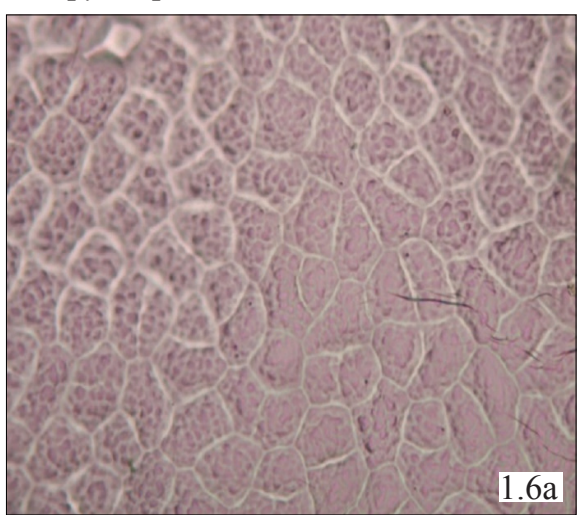

Ebenopsis ebano adaxial
Diospyros texana adaxial

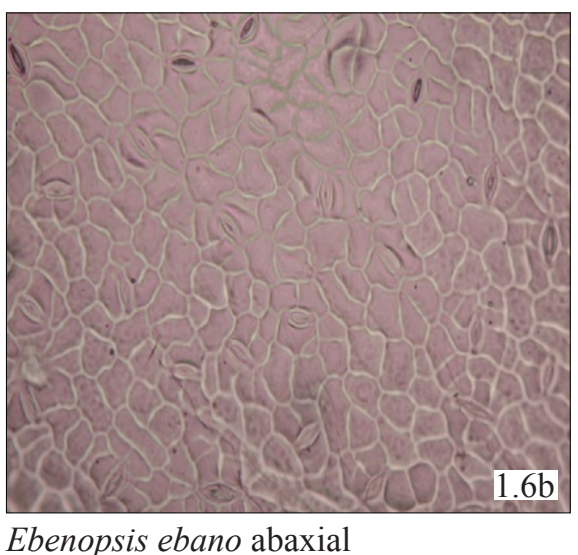

Plate 1: Absence or rare stomata on in adaxial surface and very few stomata on abaxial surface 


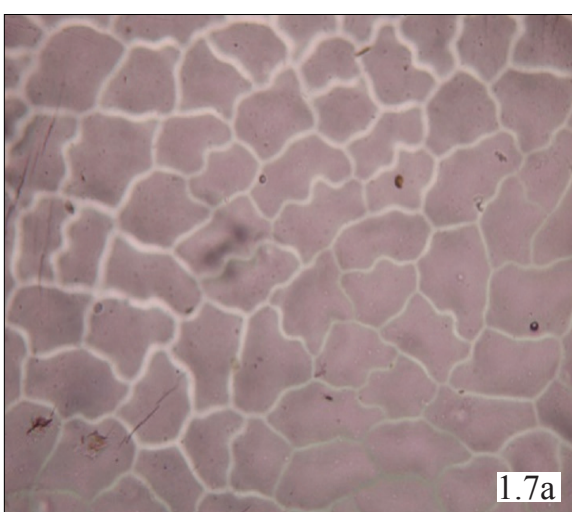

Ehretia anacua adaxial

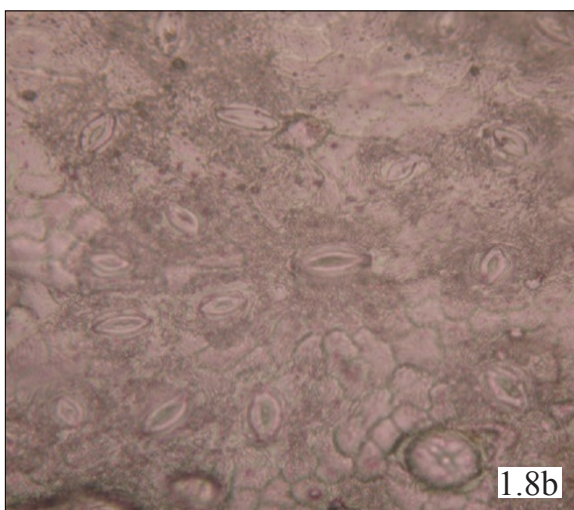

Forestiera angustifolia abaxial

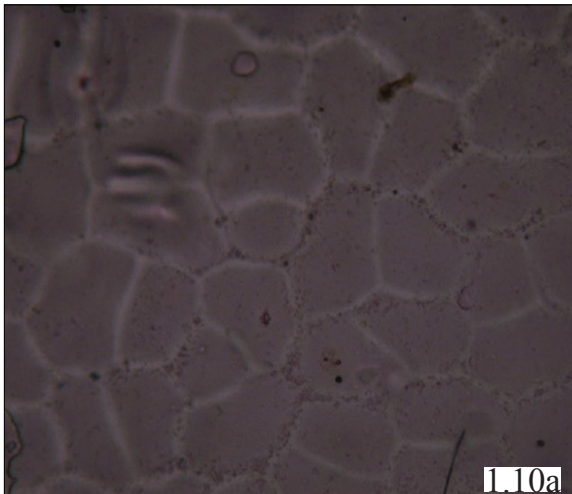

Helietta parvifolia adaxial

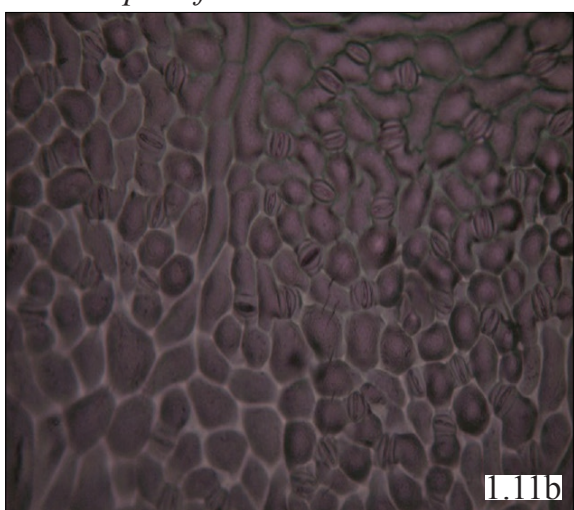

Karwinskia humboldtiana abaxial

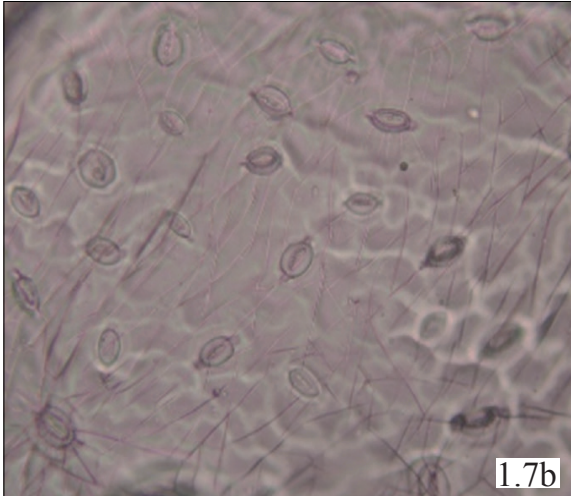

Ehretia anacua abaxial

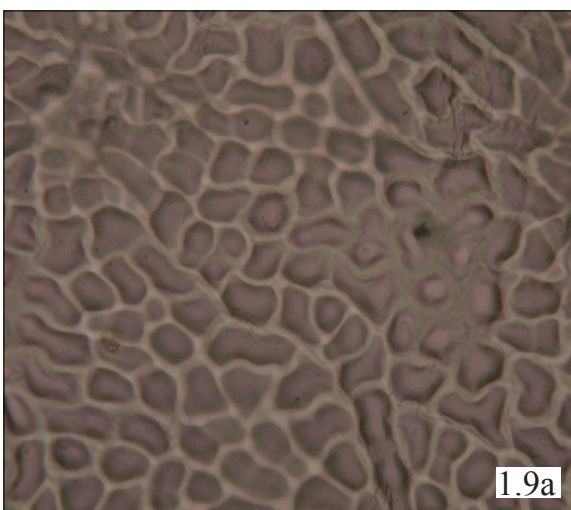

Havardia pallens adaxial

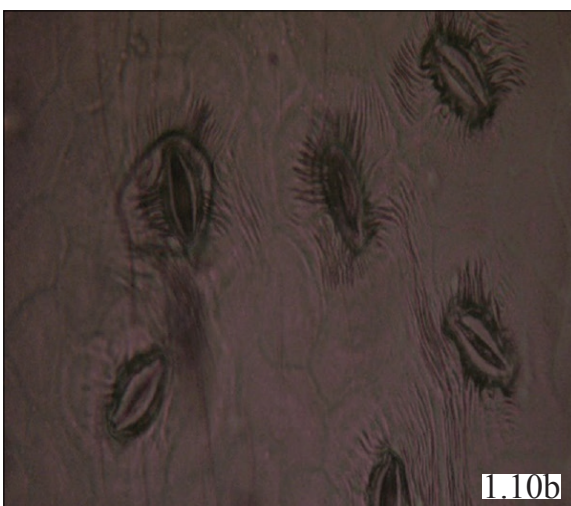

Helietta parvifolia abaxial

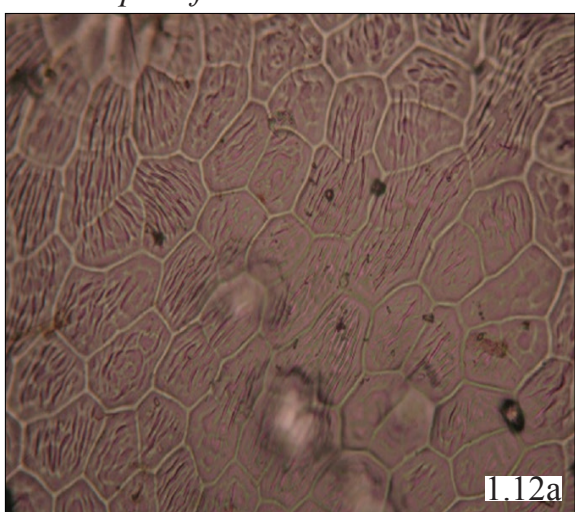

Sargentia greggii adaxial

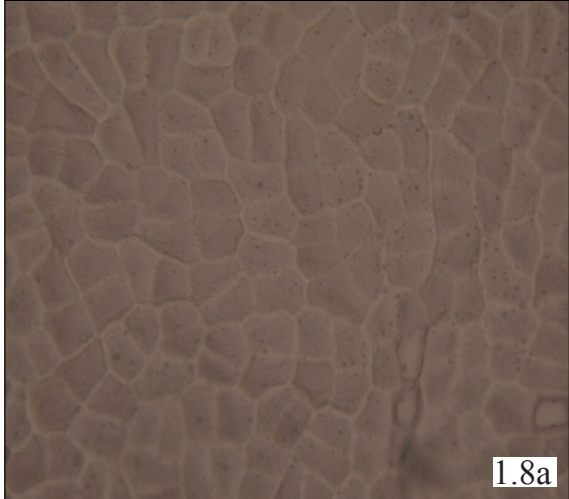

Forestiera angustifolia adaxial

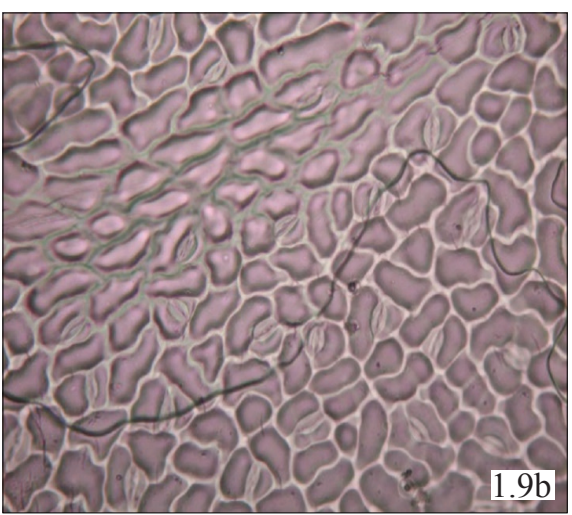

Havardia pallens abaxial

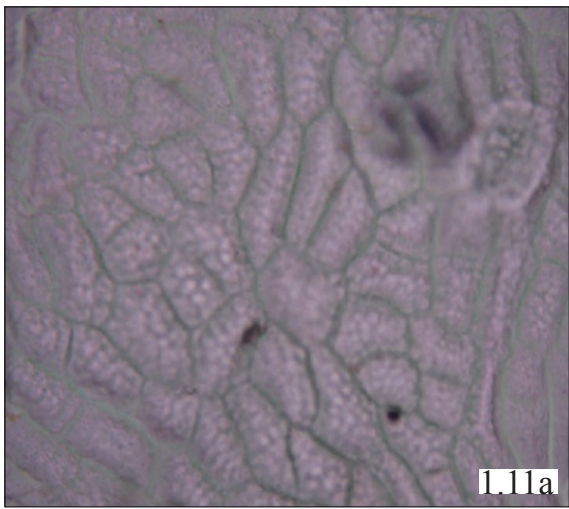

Karwinskia humboldtiana adaxial

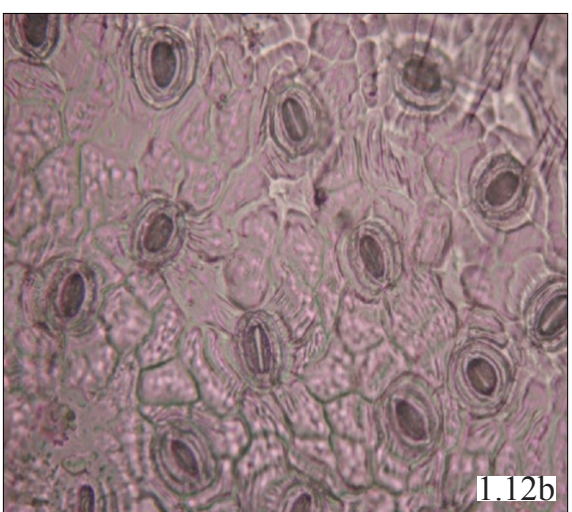

Sargentia greggii enves

Plate 1: Absence or rare stomata on in Adaxial surface and very few stomata on Abaxial Surface 


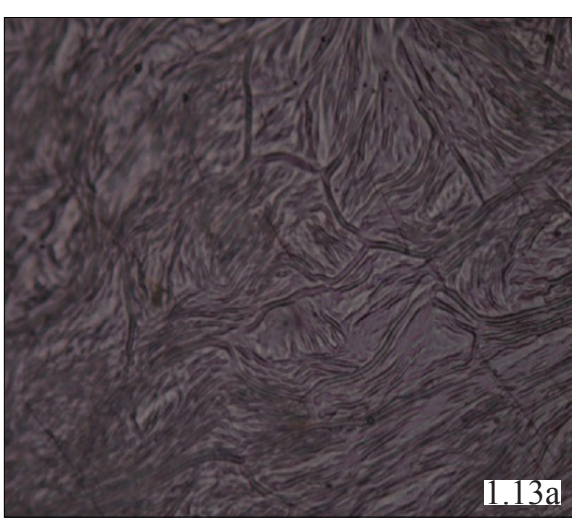

Sideroxylon celastrinum adaxial

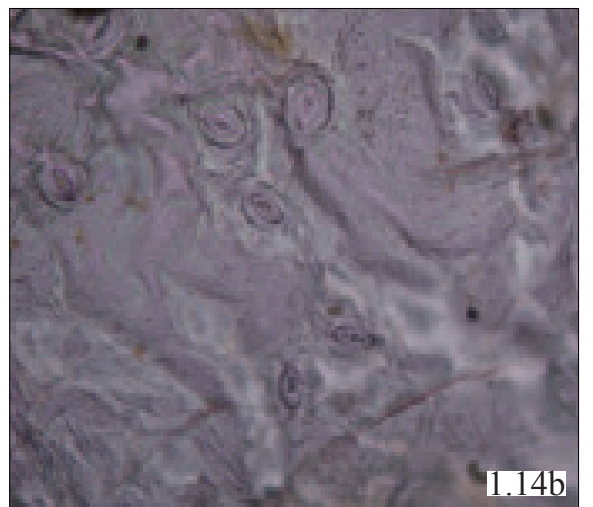

Zanthoxylum fagara abaxial

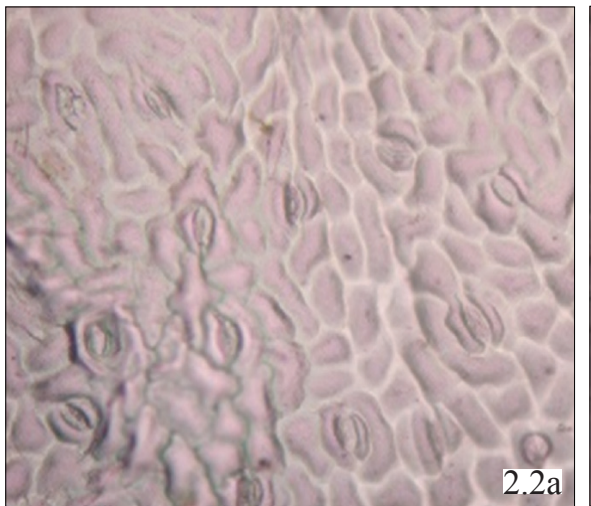

Acacia greggii var wrightii adaxial

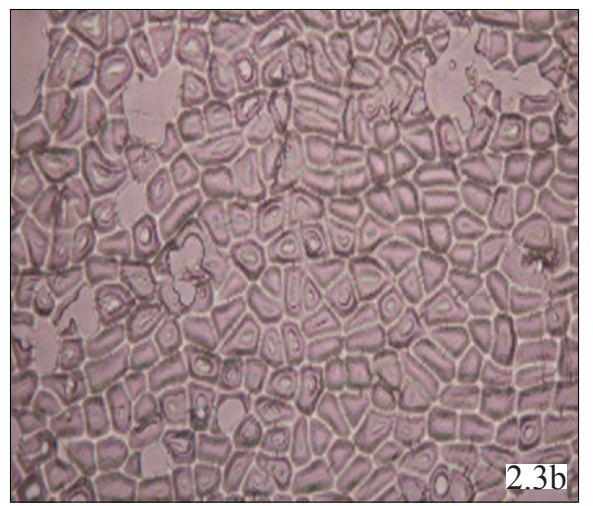

Acacia schaffneri abaxial

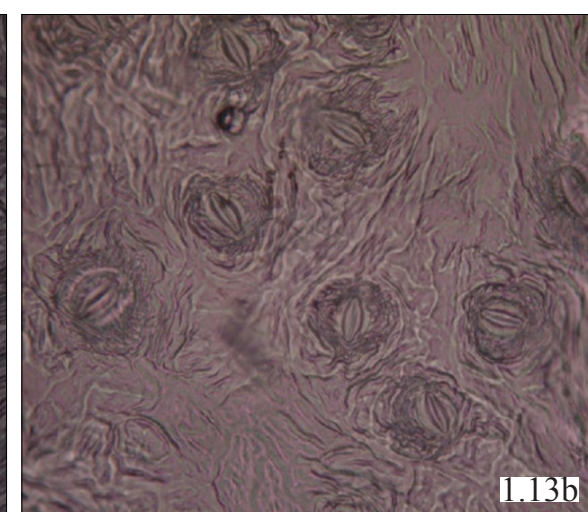

Sideroxylon celastrinum abaxial

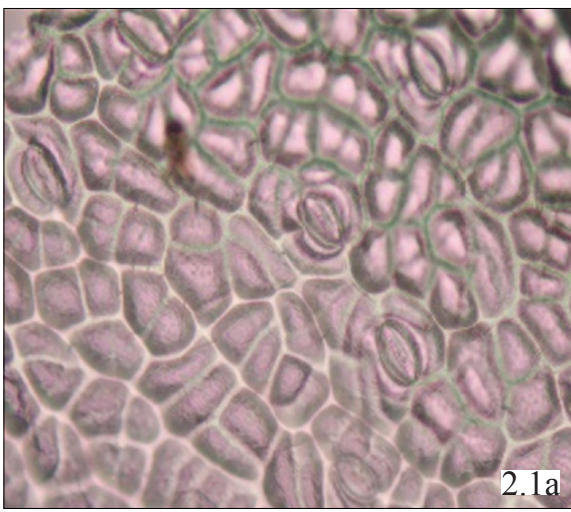

Acacia farnesiana a, adaxial

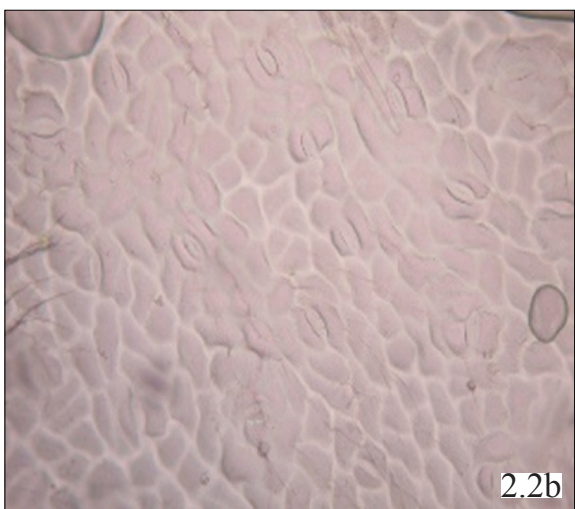

Acacia greggii var wrightii abaxial

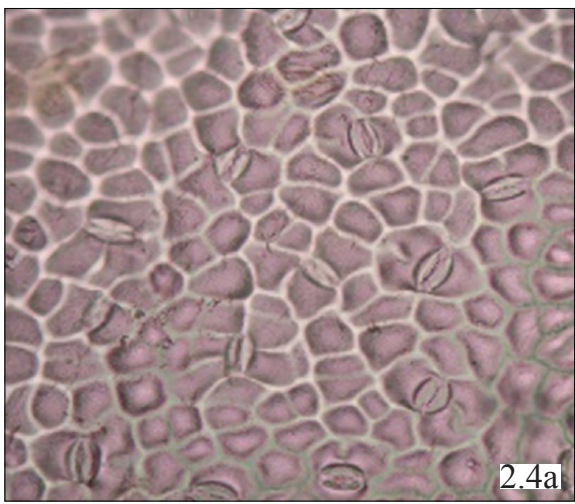

Caesalpinia mexicana adaxial

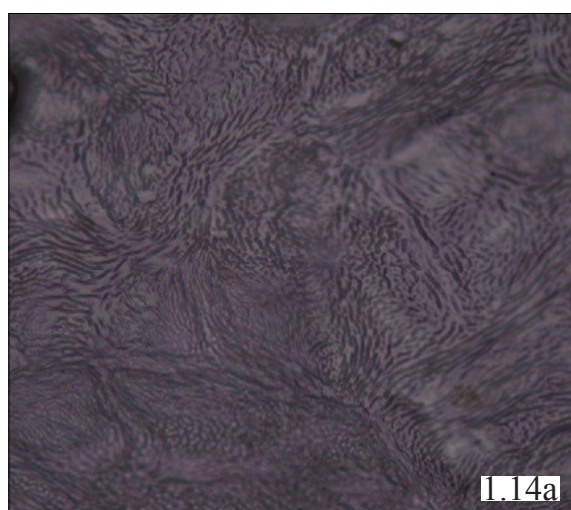

Zanthoxylum fagara adaxial

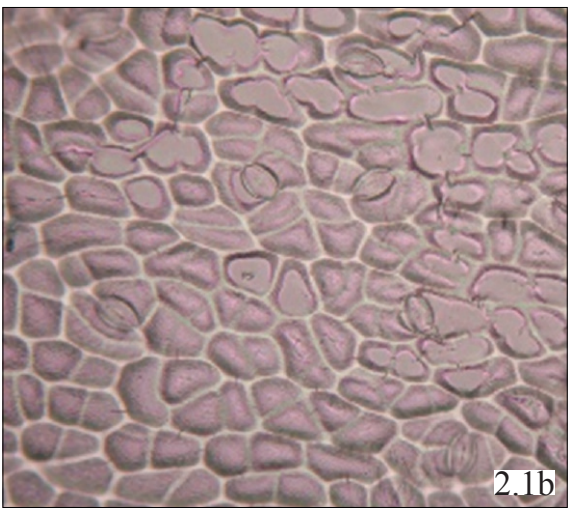

Acacia farnesiana a, abaxial

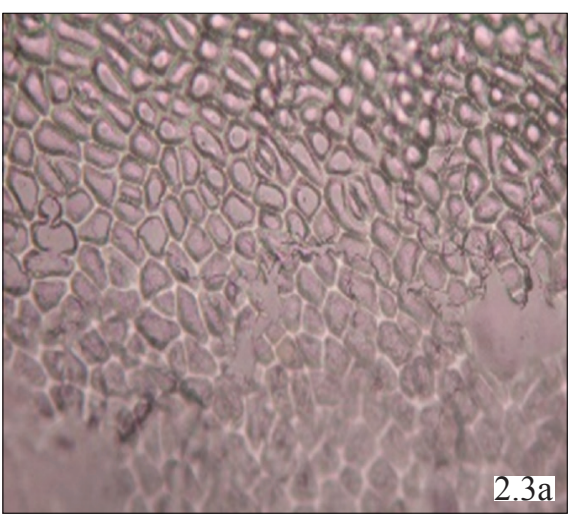

\section{Acacia schaffneri adaxial}

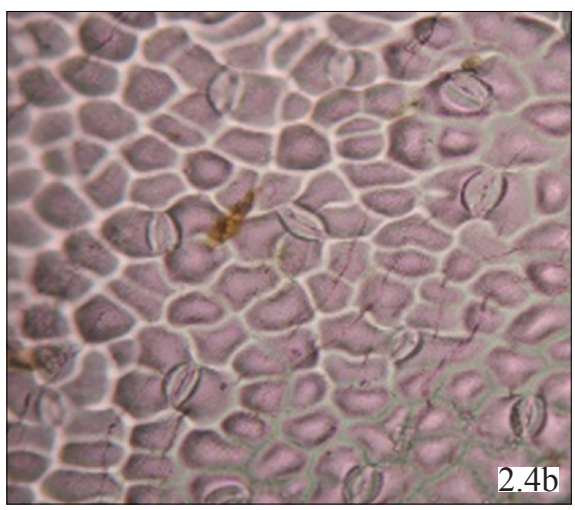

Caesalpinia mexicana abaxial

Plate 1: Absence or rare stomata on in Adaxial surface and very few stomata on Abaxial Surface

Plate 2: Very few stomata in Surface Adaxial and very few stomata in surface Abaxial 


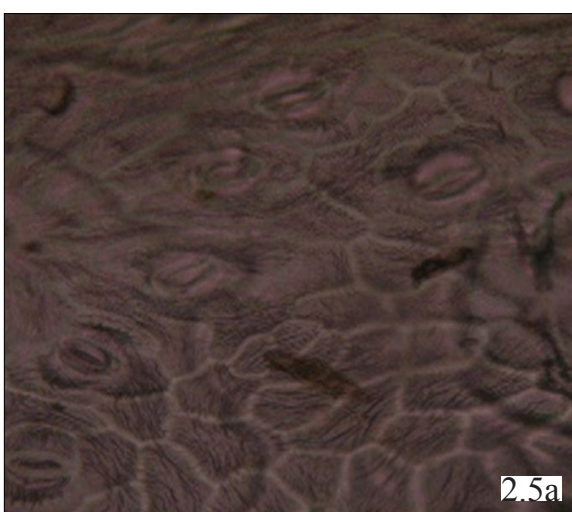

Celtis pallida adaxial

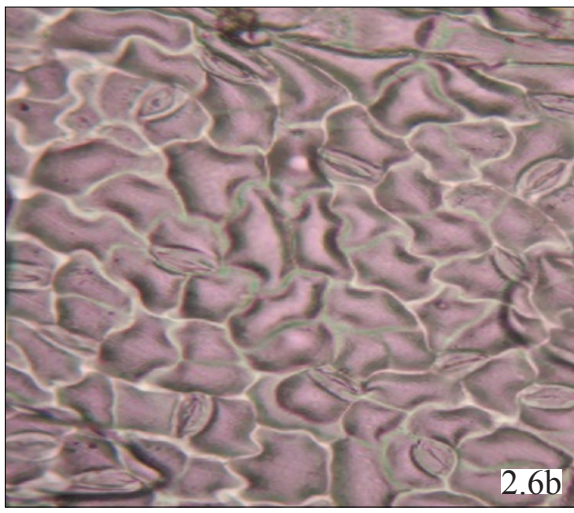

Eysenhardtia texana abaxial

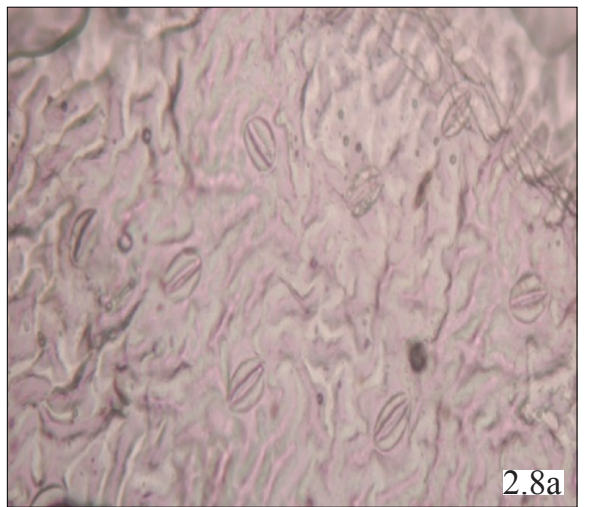

Parkinsonia aculeata adaxial

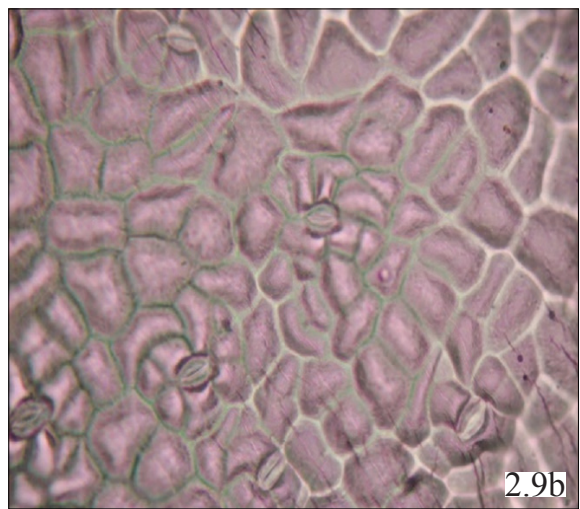

Parkinsonia texana abaxial

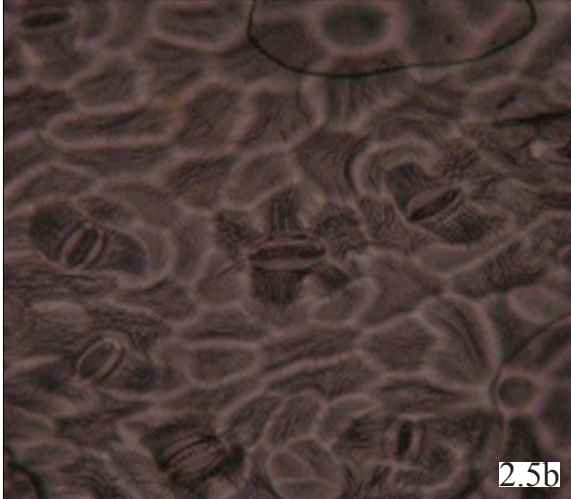

Celtis pallida abaxial

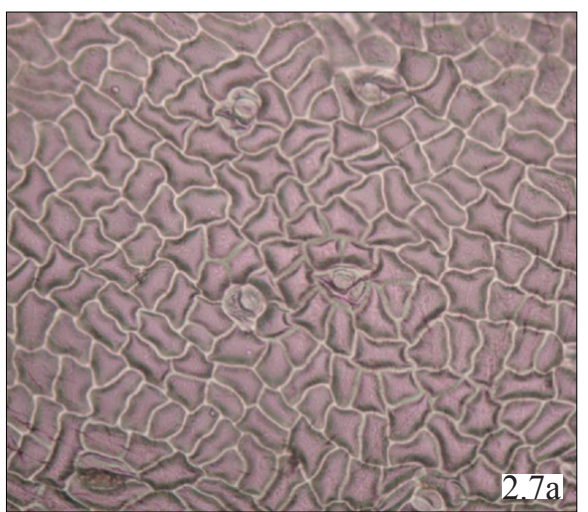

Leucaena leucocephala adaxial

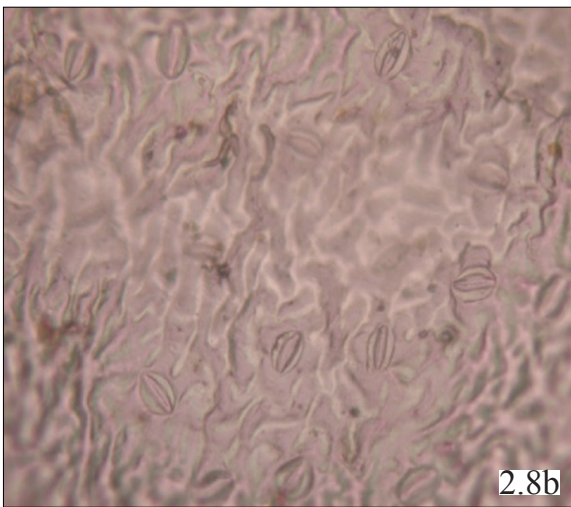

Parkinsonia aculeata abaxial

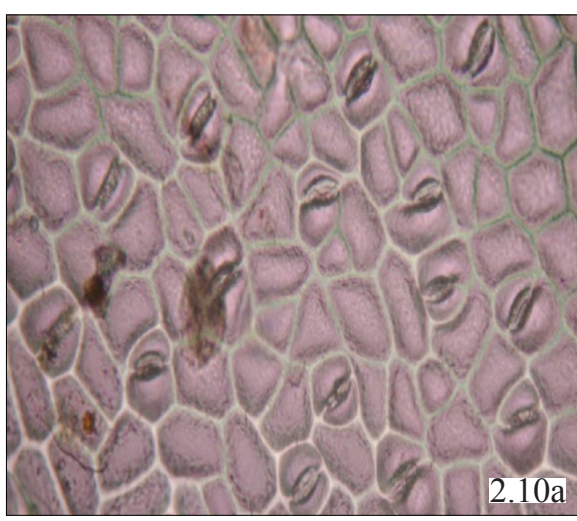

Prosopis laevigata adaxial

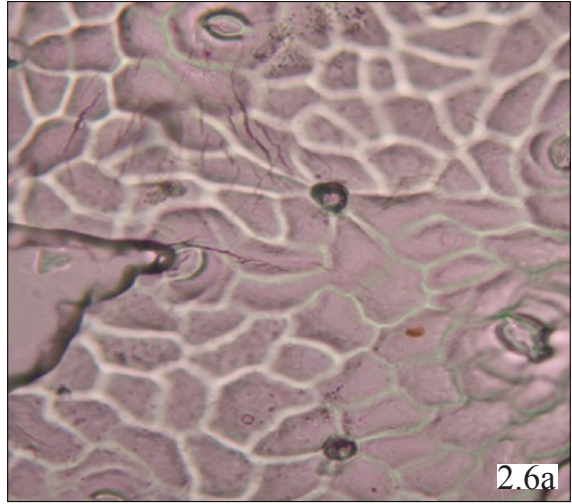

Eysenhardtia texana adaxial

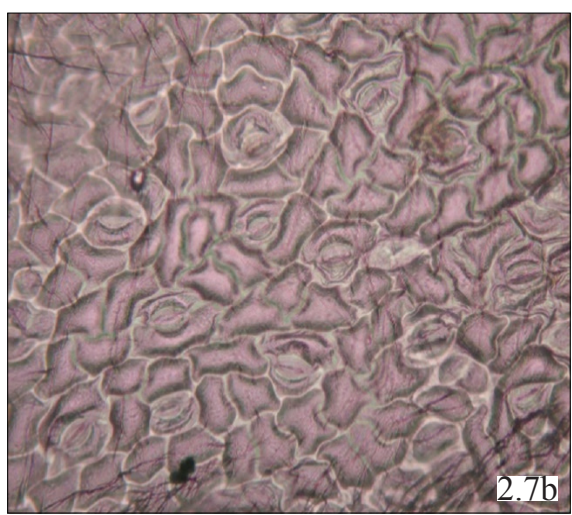

Leucaena leucocephala abaxial

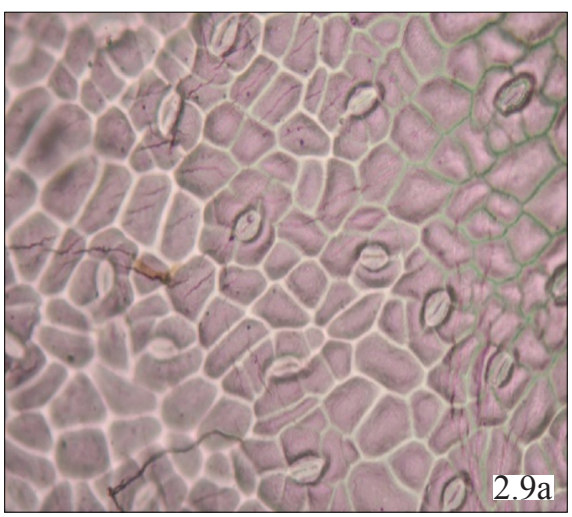

Parkinsonia texana adaxial

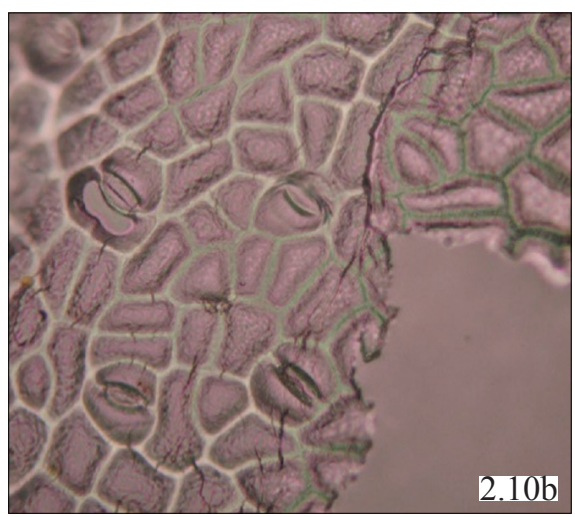

Prosopis laevigata abaxial

Plate 2: Very few stomata in Surface Adaxial and very few stomata in surface Abaxial 


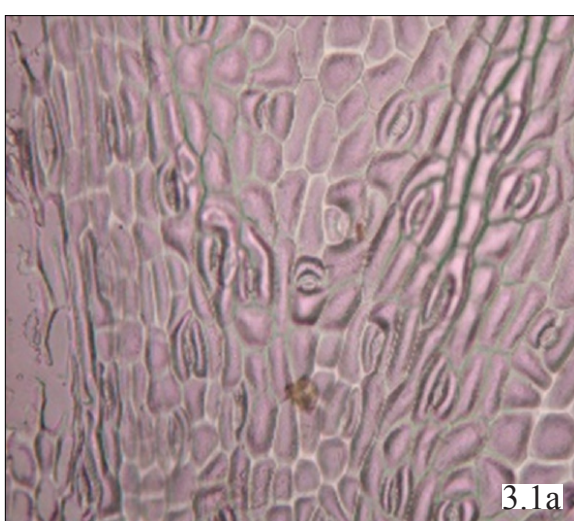

Acacia berlandieri adaxial

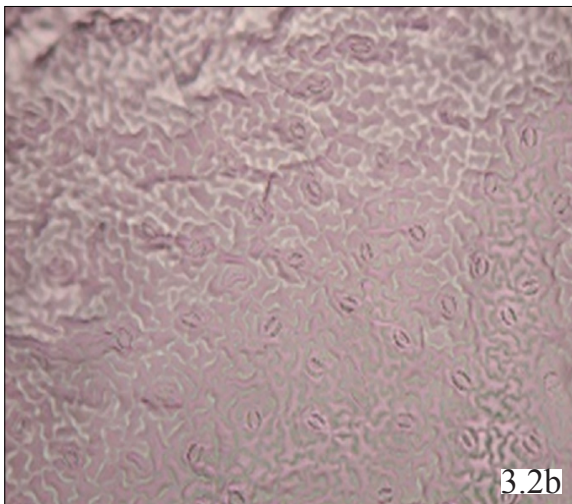

Acacia rigidula abaxial

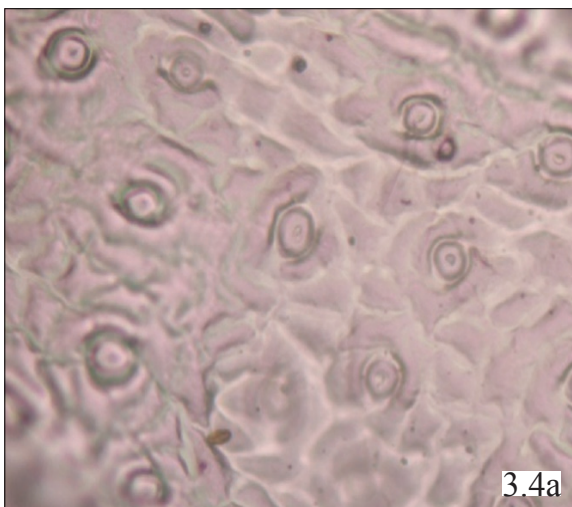

Guaiacum angustifolium adaxial

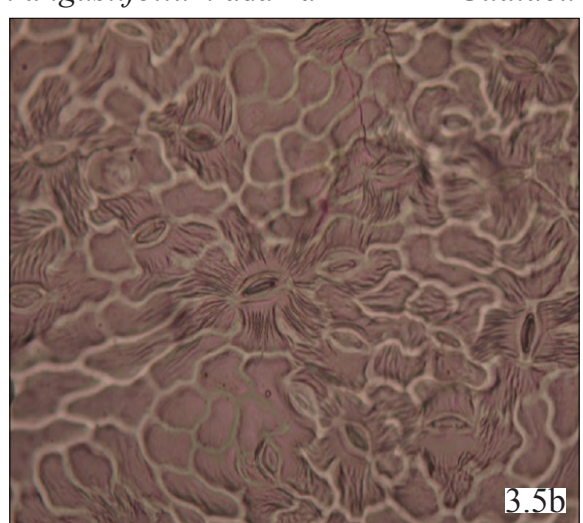

Gymnosperma glutinosum abaxial

Plate 3: Very few stomata on Adaxial surface and many stomata on Abaxial surface
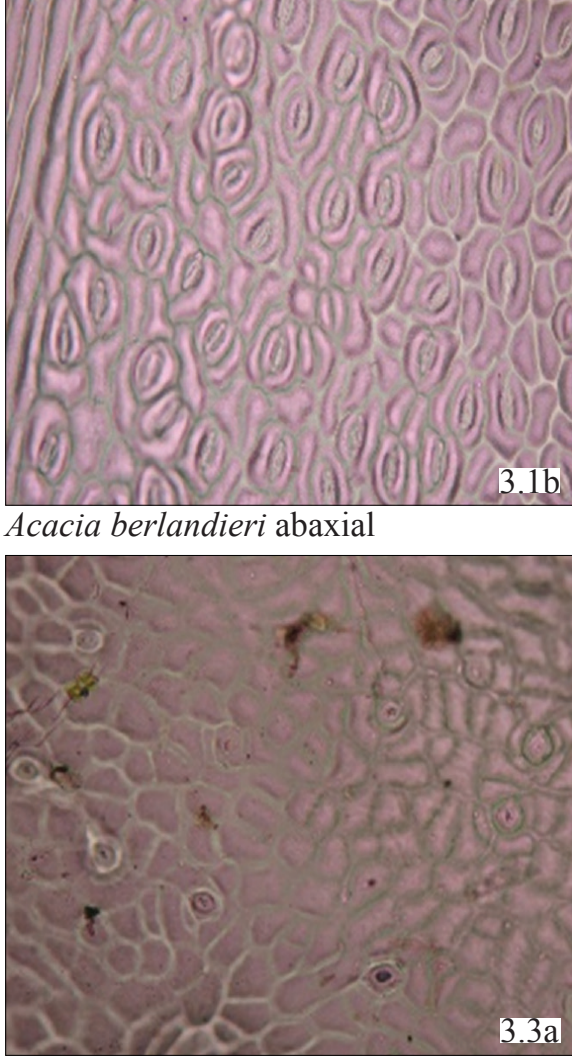

Amyris texana adaxial

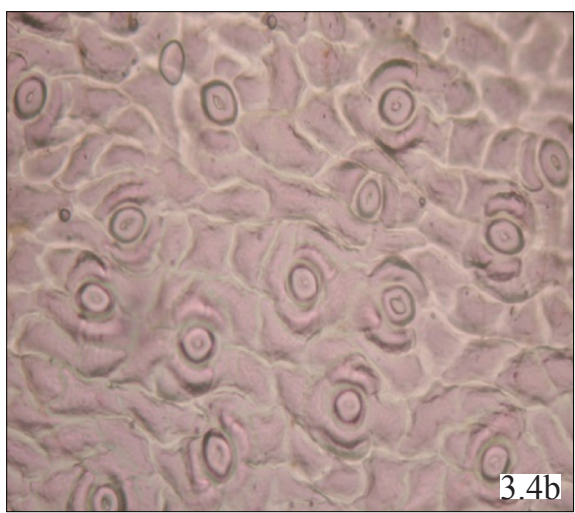

Guaiacum angustifolium abaxial

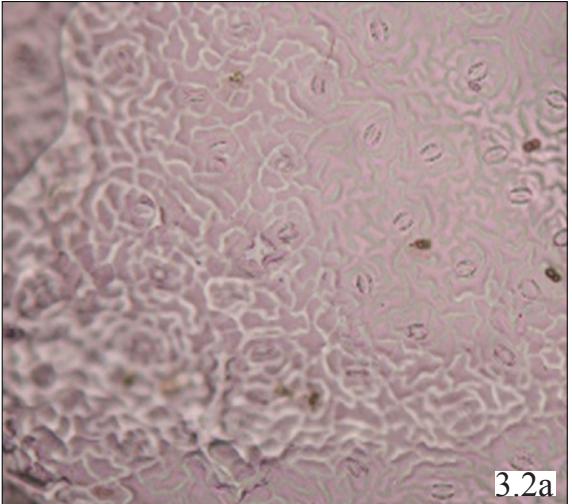

Acacia rigidula adaxial

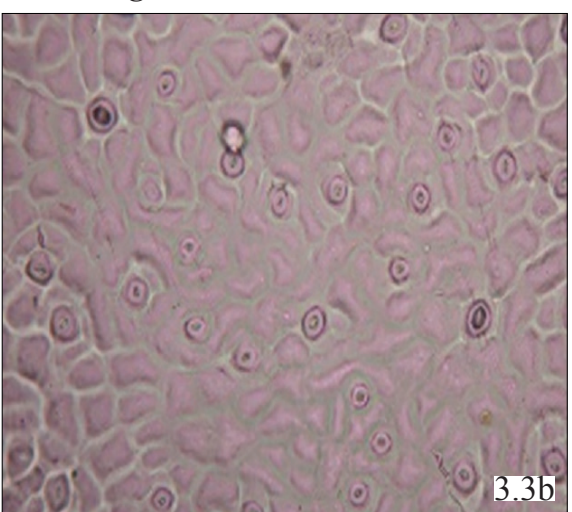

Amyris texana abaxial

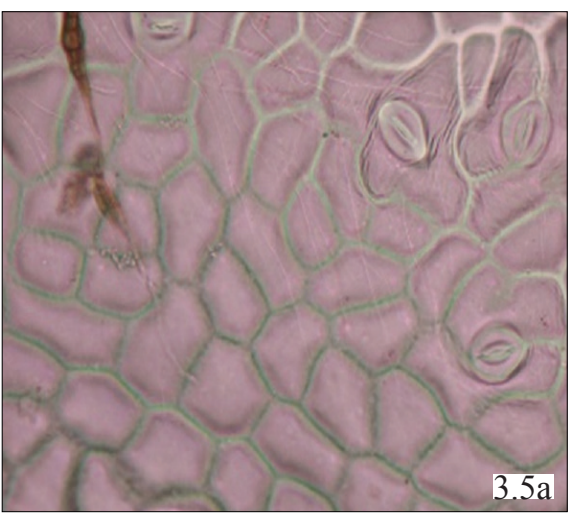

Gymnosperma glutinosum adaxial

$3.5 \mathrm{a}$

and possible adaptations to environmental stress as discussed below. The species studied in Tamaulipan thorn scrub are adapted in the semiarid environments in North-eastern Mexico, although varying in its adaptability depending on the species (Stienen et al., 1989; Rodriguez et al., 2011). Some of the species possess special traits related to adaption in the environments such as waxy leaf surface, sunken stomata, the absence of stomata on the adaxial and or abaxial surface, thereby reducing loss in transpiration mentioned before. The presence of waxy leaf surface in most of the species such as Amyris texana, Celtis pallid, Guaiacum angustifolium, Acacia berlandieri, Karwinskia humboldtiana could help in the reflectance of solar radiation, thereby keeping leaf temperature cooler. In addition the presence of sunken stomata in many 
of the species viz., Amyris texana, Celtis pallida, Guaiacum angustifolium, Forestiera angustifolia, Eysenhardtia texana, Parkinsonia texana, Gymnosperma glutinosum, Prosopis laevigata, Condalia hookeri, Diospyros palmeri, Karwinskia humboldtiana, Leucaena leucocephala, Forestiera angustifolia, Ehretia anacua helps to maintain microclimate in the stomatal cavity, thereby reduce transpiration in the semiarid environment. This hypothesis needs to be confirmed in future studies. In this respect, the variability in epicuticular wax has been observed in 37 woody species in Tamaulipan thorn scrub (Maiti et al., 2016).

The results of the present study on the importance of stomata and epidermal cell characteristics in taxonomic delimitation of the species coincide with the findings of other researchers with Souza et al. (2004) in the taxonomic delimitation of species in Piperaceae, and Chernetskyy (2012) in the genus Kalanchoe. Few anatomical characters such as stellate trichomes, cystolitic trichomes, papilate epidermis, cystolitic trichomes (Arambarri et al., 2011) are utilized to distinguish different species. The variability in the anatomical characteristics have been used in the adaptation of the species in stress environment (xeric) in Solanum nigrum in Europe and Yugoslovakia (Krstic et al., 2002), in the case of species in arid Mediterranean eco system (Rotondi et al., 2003), in orchids (Torres et al., 2006), and in the adaptation of Azadirachta indica and Millettia thonningii (Dzomeku and Enu-Kwesi 2006). The stomatal frequency in $A$. indica was very high, while it was low in Milletia thonningii, thickness of epidermis, of palisade and spongy parenchyma layers, density and length of stomata (Afas et al., 2007. Similarly density of epidermal cells, density of stomata in the adaptation of species in Chacoan forests in Argentina (Arambarri et al., 2012) and the use of few morpho-anatomical characteristics in the case of Celtis ehrenbergiana (Nughes et al., 2013). The present study mention the presence of special adaptive leaf anatomical traits which need to be confirmed in future studies.

\section{Conclusion}

A comparative study on leaf surface anatomy of woody species reveals a large variability in various leaf anatomical traits such as stomata, type, its presence, absence, among woody plant species in North-eastern Mexico. This variability in leaf surface anatomy can be effectively used in the taxonomic delimitation and adaption of the species in the environmental stress conditions. The presence of waxy leaf surface, absence of stomata, sunken stomata could predict the capacity of the species for adaptation to environmental stresses. There is a necessity to determine water relation and water stress of the species with absence or rare stomata.

\section{Acknowledgment}

Valuable technical assistance provided by Elsa Dolores Gonzalez Serna and Manuel Hernandez Charles is gratefully recognized. This research was funded by Consejo Nacional de Ciencia y Tecnologia (CONACYT, grant 250732, Convocatoria de Investigacion Ciencia Basica 2015). Useful suggestions from two anonymous reviewers helped to improve the manuscript.

\section{References}

Afas, N.A.I., Marron, N., Ceulemans, R., 2007. Variability in Populus leaf anatomy and morphology in relation to canopy position, biomass production, and varietal taxon. Annals of Forest Science 64, 521-532.

Arambarri, A.C., Monti, N., Bayon, M., 2012. Coanatomia foliar de arbustos y arboles del Distrito Chaqueno Oriental de la Argentina. Bonplandia 21, 5-26.

Arambarri, A.M., Novoa, M.C., Bayon, N.D., 2011). Anatomia foliar de arbustos y arboles medicinales de la region chaquena semiarida de la Argentina. Dominguezia 27, 5-24.

Chernetskyy, M.A., 2012. The role of morpho-anatomical traits of the leaves in the taxonomy of Kalanchoideae Berg. Subfamily (Crassulaceae DC.). Modern Phytomorphology 1, $15-18$.

Coutinho, I.A.C., Rando, J.G., Conceiçao, A.D.G., Meira, R.M.S.A., 2016. A study of the morpho anatomical characters of the leaves of Chamaecrista (L.) Moench sect. Apoucouita (Leguminosae-Caesalpinioideae) Acta Botanica Brasilica-doi:10.1590/0102-33062016abb0035.

Dzomeku, B.M., Enu-Kwesi, L., 2006. Ecophysiological study on two urban forestry species (Azadirachta indica and Millettia thonningii) in Ghana. Journal of the Botanical Research 1, 134-138.

Garcia, M.D., Jauregui, Medina, E., 2008. Adaptaciones anatomicas foliares en especies de Angiospermas que crecen en la zona costera del Estado de Falcon (Venezuela). Acta Botanica Venezuelica 31, 291-306.

Rodriguez, H.G., Cantu Silva, R.G., Ramirez, L., 2011. Potencial hidrico xilematico en cuatro especies arbustivas nativas del noreste de Mexico. Revista Chapingo Serie Ciencias Forestales y del Ambiente Edicion Especial, XVII: 97-109.

Krstic, L.N., Merkulov, L.S., Boza, P.P., 2002. The variability of leaf anatomical characteristics of Solanum nigrum L. (Solanales, Solanaceae) from different habitats. In: Proceedings for Natural Sciences, Matica Srpska Novi Sad, 102, 59-70.

Maiti, R., Rodriguez, H.G., Kumari, A., 2016. Variability 
in Epicuticular Wax in 35 Woody Plants in Linares, Northeast Mexico. Forest Research 5, 162. http://dx.doi. org/10.4172/2168-9776.1000162.

Noman, A., QAli, M.H., Ameed, 2006. Comparison of leaf anatomical characteristics of Hibiscus rosa-sinesis grown in Faislabad region. Pakistan Journal of Botany 6, 199-206.

Nughes, L., Colares, M., Hernande, M., 2013. Morfo-anatomia de las hojas de Celtis ehrenbergiana (Celtidaceae) desarrolladas bajo condiciones naturales de sol y sombra. Bonplandia 22, 159-170.

Ozdemir, A.Y., Ozdemir, C., 2010. Statistical comparative leaf anatomy of some Crocus Linn taxa. Asian Journal of Mathematics and Statistics 3(1), 16-24.

Reyes Hernandez, V.J., Vargas Hernandez, J.J., Lpez Upton, J., 2005. Variacion morfologica y anatomica en poblaciones Mexicanas de Pseudotsuga (Pinaceae). Acta Botanica Mexicana 70, 47-67.
Rotondi, A.F.C., Rossi Asunis., Cesaraccio, C., 2003. Leaf xeromorphic adaptations of some plants of a coastal Mediterranean macchia ecosystem. Journal of Mediterranean Ecology 4, 25-35.

Sonibare, M.A., Jayyeola, A.A., Agunyomi, A., 2016. Comparative leaf anatomy of Ficus Linn. (Moracea) from Nigeria. Journal of Applied Science 6(15), 3016-3025.

Souza, L.A., Moscheta, I.S., Oliveira, J.H.G., 2004. Comparative morphology and anatomy of the leaf and stem of Peperomia dahlstedtii C.DC., Ottonia martiana MIQ and Piper diospyrifolium Kunth (Piperaceae). Gayana Botanica 61, 6-17.

Stienen, H., Smits, M.P., Reid, N., 1989. Ecophysiology of 8 woody multipurpose species from semiarid North-eastern Mexico. Annals of Forest Science 6, 454-458.

Torres, J.L., Laskowski, Sanabria, M.E., 2006. Effecto del ambiente de desarrollo sobre la anatomia de la epidermis foliar de Cattleya jenmanii Rolfe. Bioagro18, 93-99. 